POLSKA AKADEMIA UMIEJĘTNOŚCI

Hanna Kowalska-Stus

Uniwersytet Jagielloński

\title{
NAJNOWSZA ROSYJSKA KRYTYKA KULTURY MASOWEJ. KIERUNKI I TENDENCJE
}

\section{THE NEWEST RUSSIAN CRITICISM ABOUT POP CULTURE. DIRECTIONS AND TENDENCIES}

\begin{abstract}
Streszczenie
Celem artykułu jest ukazanie specyficznych dla humanistyki rosyjskiej stanowisk wobec współczesnych zjawisk kulturowych. Wybrano prace socjologów, aby pokazać odmienność metodologiczną w podejściu do badań kulturoznawczych socjologów zachodnich, w tym także polskich, i rosyjskich. Badacze rosyjscy podkreślają, że we współczesnej rzeczywistości kulturowej najbardziej zagrożony jest człowiek jako podmiot. Dlatego trzeba skoncentrować się na nim. Sama globalizacja z jej kulturą ma o wiele mniejsze znaczenie lub jej istnienie jest wręcz negowane. Natomiast głównym zadaniem dla współczesnego człowieka jest pozostanie człowiekiem. Dlatego, aby zdiagnozować współczesną popkulturę, nie wystarczy analizować jej poszczególnych zjawisk, lecz trzeba potraktować ją jako skutek niewłaściwego ukierunkowania kultury chrześcijańsko-europejskiej. Całkowicie nieznane w badaniach zachodnich jest zagadnienie eschatologizmu kultury zwane przez Andrieja Fursowa historyczno-systemową finalistyką. Dlatego krytyce poddany został, wylansowany przez Rousseau, prezentyzm, będący normą współczesnej popkultury.
\end{abstract}

\section{Summary}

The aim of the article is to show attitude specific for Russian humanities in respect of the contemporary cultural phenomena. Sociologists' works were chosen in order to present methodological distinctness in approach to cultural research of western sociologists, including Polish and Russian ones. Russian researchers emphasize that in modern cultural reality man is most at risk, as a subject. Thus, man has to be the focus of attention. Globalization itself and its culture matters less or its existence is simply negated. Whereas, the main task for the present-day 
man is remaining a human. Therefore, in order to diagnose the contemporary pop-culture it is not sufficient to analyse its individual phenomena but one has to treat it as a result of improper targeting of Christian-European culture. Entirely unknown in western research is the issue of culture eschatologism which Andriej Fursow calls history-systemic finalism. Thus, presentism promoted by Rousseau which was a norm of contemporary pop-culture came under criticism.

Słowa kluczowe: Rosja, kultura masowa, współczesna socjologia rosyjska Keywords: Russia, pop culture, russian contemporary sociology

Celem artykułu jest analiza stanowiska współczesnych wpływowych rosyjskich socjologów reprezentujących poglądy konserwatywne wobec kultury współczesnej.

Rosyjska socjologia bardzo szybko zapoznała się z zachodnimi opracowaniami na temat kultury współczesnej i, zgodnie z tradycją humanistyki rosyjskiej, odniosła się do tej spuścizny twórczo i krytycznie. Charakterystyczne dla niej jest spojrzenie syntetyczne łączące diachronię z synchronią, dążenie do uchwycenia genezy współczesnych zjawisk kulturowych, wyodrębnienie istotnych nurtów kulturotwórczych i śledzenie ich historycznego rozwoju. W wypowiedziach ujawnia się istotna cecha kultury rosyjskiej i opisującej ją humanistyki - eschatologizm. Widoczna jest też potrzeba polemiki z marksistowską metodologią.

\section{Andriej Fursow}

Andriej Fursow, znany socjolog i historyk, profesor RGGU (Российский государственный гуманитарный университет; Państwowy Rosyjski Uniwersytet Humanistyczny), aktywny prelegent występujący w mediach, stawia tezę, która może stanowić historyczno-kulturologiczne uzupełnienie wielu szczegółowych analiz kultury masowej, dokonanych przez badaczy poszczególnych zjawisk z nią związanych, takich jak: postmodernistyczna estetyka, urynkowienie kultury, mit, uniwersalizm, anonimowe autorstwo ${ }^{1}$.

Fursow przedstawia się jako badacz społecznej eschatologii, historyczno-systemowej finalistyki. W takim stadium znajdują się, według niego, niegdyś chrześcijańskie i kapitalistyczne społeczeństwa. Jego podejście nie jest zgodne z istniejącą metodologią nauk społecznych. Jest ona bowiem ukierunkowana na badanie uschematyzowanych struktur. Fursow krytykuje także metodologię marksistowską jako systemocentryczna, nie jest ona w stanie interpretować społeczeństwa w stadium rewolucji, gdzie rolę odgrywa wiele podmiotów, a ich działanie nie jest związane ani z logiką epoki minionej, ani następującej. Konieczna jest wiedza klasmologiczna (grec. клазмос-zerwanie).

${ }^{1}$ А. Фурсов, Колокола истории, http://royallib.com/read/fursov_andrey/kolokola_istorii.html\#20480 (dostęp: 10.11.2016). 
Ilustruje to słowami słynnego dialogu Hamleta: „The time is out of joint” - „Świat wyszedł z formy i mnież to trzeba wracać go do normy". Kiedy następuje koniec ładu społecznego, znika hierarchia wartości, nic nie stoi na przeszkodzie w oddziaływaniu absurdalnych incydentów. Można dodać do tego spostrzeżenia, że kultura w czasach kryzysu jest odzwierciedleniem tego zjawiska, jest niezdolna do stawiania pytań metafizycznych, rozmywa się w szczegółach, brak w niej hierarchii i formy.

\section{Kultura - pancerz ustroju społecznego}

Fursow podkreśla, że w Rosji to komunizm stworzył społeczeństwo masowe i współczesną rosyjską masową cywilizację. Teraz jednak trzeba myśleć o stworzeniu nowej formy o charakterze geokulturowym, geoekonomicznym i geopolitycznym pancerza dla nowej struktury, która powstaje w Rosji i która nie będzie już Rosją dawną ani też imperium nowej technicznej rewolucji. We współczesnym świecie nastapił kres historyczno-kulturowego i socjogenetycznego programu zarówno chrześcijaństwa, jak i kapitalizmu. Współczesny świat rewolucji naukowo-technicznej i postmodernizmu Fursow diagnozuje jako Sąd Ostateczny (Страшный Суд) wyrokujący zgodnie z wartościami chrześcijańskimi nad spuścizną chrześcijańską.

\section{Człowiek w chrześcijaństwie}

Fursow dowodzi, że główna odpowiedzialność za stan współczesnej kultury spoczywa na chrześcijanach, którzy podbili cały świat i nie biorą za to odpowiedzialności, pozostawiając ogromne obszary we władaniu wyzutego z chrześcijaństwa kapitału ogołoconego z wartości, którymi kierował się kapitalizm. Człowiek kultury chrześcijańskiej, nawet niewierzący, pozostając w takiej przestrzeni, jest pozostawiony sam sobie, jest zaledwie myślącym atomem. Dlatego dziś chrześcijanie nie są w stanie zrealizować żadnych społecznych, ekonomicznych ani politycznych projektów. W początkach swego istnienia chrześcijaństwo umiało zniwelować różnice między chrześcijańskim uniwersalizmem i kulturowym partykularyzmem - zauważa Fursow. Ta sfera została całkowicie zaprzepaszczona, gdyż na pierwszy plan wysunął się zysk, co sprowadza myślenie o uniwersum do kategorii czysto ekonomicznych. Fursow początek tego procesu zauważa już w XIV w. w momencie, kiedy nastąpił konflikt między czynnikiem cywilizacyjno-przestrzennym i uniwersalno-temporalnym kultury europejskiej. Kapitalizm stał się alternatywą. Uniwersalizm zastąpił powszechnością, która stawiała przed sobą inne cele niż chrześcijaństwo. Fursow uważa, że kapitalizm był mniej kulturotwórczy niż chrześcijaństwo. Nie był w stanie rozwiązać sprzeczności między zagospodarowaną przestrzenią i czasem w rozumieniu chrześcijańskim, eschatologicznym, między cywilizacją i chrześcijańskim uniwersalizmem. 
Ten wywód może być niejasny dla przedstawicieli kultury łacińskiej. Nawiązuje bowiem do tradycji eschatologii grecko-bizantyjskiej, w której nie tylko człowiek zmierza ku przebóstwieniu w eschatologicznej przestrzeni i czasie, lecz także całe stworzenie. Dlatego przestrzeń odgrywa tu rolę zbawczą. Myśl Fursowa należy interpretować w ten sposób, że kultura łacińska przesycona wartościami chrześcijańskimi nie była zdolna uczynić przestrzeni świata przestrzenią zbawcza, tym bardziej nie mógł tego uczynić kapitalizm, choć upowszechnił skutecznie swoje metody i cele cywilizacyjne. Kapitalizm skapitalizował stosunki międzyludzkie, skapitalizował i umasowił kulturę, a za jej pośrednictwem upowszechnił swoje wartości. Wypracował nowe instrumenty, zaczął propagować nowe treści. Dopóki istniały tereny ekspansji, chrześcijaństwo, jako wehikuł kultury starego świata, spełniało swoją rolę i kapitalizm z nim współpracował. Kiedy ekspansja się zakończyła, osamotniona jednostka pozbawiona została podwalin uniwersalnego systemu o charakterze eschatologicznym. Ufilozoficznione chrześcijaństwo wsparte na Marku Aureliuszu i Ekleziastesie nie pomogło jej w konfrontacji z nieskończonością - podsumowuje Fursow.

\section{Nowa estetyka}

Świat współczesny przeżywa kryzys systemowy, rewolucję społeczną, okres chronoklazmy - rozdarcia czasu. Podobnie było w kulturze rosyjskiej po rewolucji. Wtedy także pojawiła się nowa estetyka w kulturze. W tej sytuacjinowe idee mieszają się ze starymi, a potem następuje surowy porządek, społeczna asceza. Ten porządek może wprowadzić tylko nowy podmiot. Po rewolucji październikowej taką rolę odegrał Stalin. Charakterystyczne jest, że Fursow posługuje się terminem: „разрыв установление", wskazując na organiczny związek tych dwóch zjawisk. Pesymizm diagnozy współczesnej kultury Fursowa polega na tym, że nie dostrzega on możliwości ustanowienia nowego porządku. Dziś kultura rodzi potworki, które mszczą się na człowieku i historii za swoją ohydę, tworząc zwariowany świat, w którym zwyciężają „racjonalni idioci z żelazną wolą”. Horyzontalny związek przyczynowo-skutkowy burzy normalny - wertykalny.

\section{Globalizacja}

Powyższe rozważania skłaniają Fursowa do postawienia tezy, że stan współczesnej kultury wskazuje, iż globalizacja jest zjawiskiem wirtualnym, jednolitość świata prawdopodobnie jest fikcją, a świat w rezultacie dąży do atomizacji. Społeczeństwo komunikacyjno-informatyczne nie stanowi jednolitego światowego systemu, jest siecią luźno powiązanych enklaw. Można się z tym zgodzić, gdyż faktycznie kultura jest pozornie zglobalizowana. Wydaje się taka, ponieważ operuje podobną formą 
i techniką upowszechnienia, ale jej wartości i treści się różnią. Obniżający się poziom odbiorców nie pozwala im tych różnic rozpoznać, zdolni są koncentrować swoją uwagę wyłącznie na formie. Charakterystyczna jest poetyka buntu, walki, irracjonalności, defensywy, kultu rozrywki. Kultura skojarzona jest z rozrywką, a ta z przestrzenią wirtualną. Zaciera się granica między fikcją a realnością, dawny odbiorca może być jednocześnie autorem i bohaterem, gladiatorem, zabójca, dinozaurem itd. Rozrywki czasu wolnego, zauważa Fursow, alienują człowieka, tak jak wcześniej alienowała, według Marksa, praca. Kradną mu czas i przestrzeń. Ta rzeczywistość jest bardziej opresyjna i efektywna niż komunizm, nie straszy, ale zanęca, nie ukazuje świetlanej przyszłości, tylko przyjemną teraźniejszość. Uniwersalna idea czy egalitarna przyszłość nie są już pożądane. Docenia się partykularyzm multikulturowy. Kultura masowa jest tu nie jednym z narzędzi, lecz elementem systemu, trudno ją zdefiniować według klasycznego rozumienia. Może być zarówno opakowaniem, formą, jak i produktem czy narzędziem. Te uwagi Fursowa można zilustrować przykładem rysunkowych filmów dla dzieci, które spełniają zarazem kryteria rozrywki, edukacji i reklamy. Edukacja jest ukierunkowana na cele praktyczne i nauki ścisłe. Nad wszystkim góruje zasada marketingowa, wywierająca presję na psychikę dziecka, by jego emocjonalne zaangażowanie po stronie bohaterów przetworzyć w potrzebę bezpośredniego z nimi obcowania, co wymusza serię zakupów określonych gadżetów. Podobnie amorficznym gatunkiem stała się reklama, z której czasem trudno wyłowić, jaki produkt reklamuje, gdyż posługuje się skomplikowaną i zaszyfrowaną fabułą. To samo dotyczy beletrystyki, spektakli teatralnych, mody, sztuk plastycznych, architektury, a nawet programów nauczania w szkołach.

\section{Antropologia}

Charakterystyczna dla humanistyki wyrosłej ze źródeł grecko-prawosławnych jest interpretacja rzeczywistości kulturowej ufundowana na antropologii. Wychodzi ona z założenia, że kulturę można zrozumieć, jeśli dowiemy się, jak ona definiuje człowieka i jego miejsce w świecie. Jest to typowe dla tradycji prawosławnej, która pozostała chrystocentryczna i w tej perspektywie postrzega człowieka. Ale ważne są tu też korzenie greckie, które narzucają ontologizm i kosmizm w postrzeganiu rzeczywistości. Stąd w horyzoncie myślenia istnieje perspektywa eschatologiczna związana $\mathrm{z}$ ideą przebóstwienia całego stworzenia. $Z$ tego punktu widzenia człowiek współczesny - zindywidualizowany atom, jak go określa Fursow, jest fikcją. Podkreśla, że we współczesnej rzeczywistości kulturowej najbardziej zagrożony jest człowiek jako podmiot. Dlatego trzeba skoncentrować się na nim. Sama globalizacja z jej kulturą ma o wiele mniejsze znaczenie.

Głównym zadaniem dla współczesnego człowieka - pisze autor - jest pozostanie człowiekiem. W tym sensie wracamy do korzeni chrześcijaństwa i powinniśmy za- 
wołać: „Иисус, дай нам руку, помоги в немой борьбе” („Panie Jezu, podaj nam rękę, pomóż w niemej walce"). To zawołanie jest ratunkiem przeciw degeneracji (w sensie ontologicznym).

Ułomnością współczesnego człowieka jest odcięcie się od informacji o rzeczywistym obrazie świata; Fursow nazywa go homodisinformaticus. Ten człowiek nie posiada wymiaru duchowego, światopoglądu, wiary i przekonań. Nie przejawia potrzeb duchowych w kontaktach ze światem zewnętrznym, nie wyraża ich w wytworach kultury, sztuki i innych formach działalności, a także w obcowaniu z pomnikami kultury. Nie jest zdolny do myślenia w tych kategoriach, w konsekwencji przestaje być człowiekiem. By osiągnąć taki efekt, nie trzeba go odcinać od informacji, przeciwnie, należy go w niej utopić, żeby zawołał: „Не хочу политики, чернухи, эпидемий, катастроф; хочу покоя и развлечений”.

Jednocześnie cechą charakterystyczną współczesnej mentalności jest pogłębiająca się iluzja, że świat się globalizuje. W rzeczywistości, dowodzi Fursow, mondializują się bieżące momenty, czas teraźniejszy. Tę uwagę socjologa warto uzupełnić o obserwację, że zglobalizowana informacja ślizga się po powierzchni zdarzeń, jest fragmentaryczna, często zawiera błędy i absorbuje uwage przez chwilę. Jej masowy i powszechny charakter sprawia, że człowiek jest w niej nieustannie zanurzony, jak w bezpodmiotowej magmie, w permanentnej teraźniejszości. Znamienne jest, że pozytywną rolę przewagi prezentyzmu nad przeszłością i przyszłością głosił twórca nowożytnej kultury i antropologii Jan Jakub Rousseau w swoim traktacie Marzenia samotnego wędrowca. Dowodził on, że naturalnym i jedynie prawdziwym środowiskiem dla człowieka jest czas teraźniejszy, gdyż przeszłości już nie ma, a przyszłość jeszcze nie istnieje.

W odniesieniu do kultury rosyjskiej trzeba w tej sytuacji wziąć pod uwagę fakt, że obecny w niej był i odgrywał ważną rolę od pewnego momentu element wirtualny; przejawiał się w realizmie fantastycznym Gogola, baśni ludowej, micie symbolicznym o Grodzie Kiteżu, specyficznym rosyjskim humorze, satyrze, w której śmiech przeplata się z grozą. Ufundowany był na typowym dla estetyki bizantyjskiej realizmie symbolicznym, przenoszącym za pomocą realnych obrazów w rzeczywistość transcendentną. To jest istotna różnica między kulturą rosyjską i europejską, co ilustrująprzytoczone przez Fursowa słowa amerykańskiego znajomego z CIA, który stwierdził, że:

Приемы манипулирования людьми, отработанные на западном материале, начиная от компьютерных „стрелялок” и заканчивая сериалами, не срабатывают в России, потому что специфическая смеховая культура России сильно мешает воздействию западной пропаганды. На Западе если страшно, то не смешно, если смешно, то не страшно. По русской традиции может быть смешно и страшно одновременно ${ }^{2}$.

${ }^{2}$ А. Фурсов, Вирусные элиты и Русская культура, 10 января 2014, http://omiliya.org/article/ andrei-fursov-virusnye-elity (dostęp: 12.06.2016). 
Dlatego zachodnia wirtualna kultura masowa może w Rosji nie odnieść sukcesu.

W kontekście antropologicznym Fursow omawia także zagadnienie postępu. Według niego postęp, tak jak go definiuje cywilizacja europejska, nie jest zjawiskiem futurystycznym, to kulturowe samozakłamanie. Prawdziwie futurystyczne, zwrócone zawsze ku przyszłości, jest chrześcijaństwo. Futurystyczne było średniowiecze. Postęp to ulepszona współczesność, to historyczna i metafizyczna dywersja. I dlatego Europejczyk nie zagląda w eschatologiczną przyszłość, niczego ona mu nie obiecuje, niczego od niej nie oczekuje, kultura europejska nie ma charakteru eschatologicznego, zwróconego ku przyszłości, jak na przykład powieści Dostojewskiego. Jest skrojona według wspomnianej uznanej prawdy głoszonej przez Rousseau, że istnieje tylko teraźniejszość.

\section{Rosja-Zachód}

W tym zatomizowanym świecie tylko Rosja i Zachód posiadają jeszcze resztki cech uniwersalizmu zrodzone z chrześcijaństwa - rzeczywistego podmiotu historycznego. Dlatego między Rosją i Zachodem konieczny jest sojusz na podstawach metafizycznych. Problem polega na tym, że Rosja jest zainteresowana w odrodzeniu normalnego systemu na Zachodzie, co nie spotyka się ze zrozumieniem Zachodu, który utracił instynkt metahistoryczny. Ukierunkowanie Ameryki na kraje arabskie, a Rosji na Azję Fursow określa mianem bomby z opóźnionym zapłonem - bomby cywilizacyjnej, kulturowej, historycznej, etnicznej. Przytacza tu pogląd francuskiego ekonomisty Yves'a Laulan'a, który twierdzi, że bizantyjska strategia przetrwania, oparta na wojskowo-technicznej przewadze, korzystnych sojuszach politycznych oraz zachowaniu stabilizacji politycznej, jest pożądanym modelem dla współczesnego Zachodu³.

Problem polega na tym, że Zachód ugania się za postępem, a to właśnie przeszłość, a nie przyszłość jest realnym finałem, ostatnią fazą chrześcijańskiego podmiotu historycznego. Najbardziej prawdopodobne jest jednak to, że zarówno Europa, jak i Rosja przeniosą się do kilku na razhistorycznych epok.

\section{Projekt Rosja}

Diagnoza Fursowa co do zgubności futuryzmu koresponduje z opinią wyrażoną przez anonimowych autorów traktatu Projekt Rosja $a^{4}$ Nawiązuje on do bizantyj-

${ }^{3}$ Y.-M. Laulan, La planète balkanisée, Paris 1993, s. 341; pracował w strukturach Międzynarodowego Funduszu Walutowego, Banku Światowego i NATO.

${ }^{4}$ Проект «Россия». Исследовательский доклад группы «интелрос», http://www.intelros.org/ lib/doklady/russia.htm (dostęp: 11.10.2016). 
skiej doktryny państwa jako przestrzeni zbawczej, gdzie istnieje wyraźny podział kompetencji między tych, którzy są strażnikami Kościoła i tradycji prowadzącej do zbawienia, oraz tych, którzy do zbawienia dążą. Jest to zmodyfikowana doktryna diarchii.

Fundamentem oryginalnej państwowości rosyjskiej, potencjałem rosyjskiej cywilizacji jest, według autorów doktryny, idea imperium - pożądanej we współczesnym świecie syntezy interkonfesjonalnego państwa, syntezy rzymskiego i greckiego Katechonu (Powstrzymującego, P, II L, T). Jest to źródło współczesnego pojmowania idei Moskwy III Rzymu: syntezy kultur i etosów, pokojowej chrześcijańskiej asymilacji, ponadnarodowych i ponadkonfesjonalnych koalicji, przestrzeni chroniącej chrześcijańskie wartości przed neopogaństwem Zachodu i barbarzyństwem Południa. Są to wartości bezcenne we współczesnym świecie zdominowanym przez wojnę kultur i cywilizacji. Rosyjska Cerkiew Prawosławna postrzegana jest przez dokument jako jedyna struktura, która zachowała tradycyjny, dla historycznej przestrzeni Rosji, charakter i której wysiłki poświęcone są zachowaniu jedności. Na jej sztandarach powinno być wypisane hasło mówiące o tym, że Rosja jest krajem strzegącym tradycji, chroniącym interesy obywateli przed inwazją abstrakcyjnych humanitarnych pseudowartości. Państwo jest zobowiązane, by wspomóc działania Kościoła. Cerkiew nie może być postrzegana jako segment życia społecznego, lecz jako siła tożsama z tradycją narodowo-państwową. Jest to postulat sprzeczny z koronną zasadą współczesnej demokracji - rozdziału państwa od Kościoła. Potwierdza to wyrażone przez autorów życzenie, by tradycję uczynić z powrotem tym, czym ona w rzeczywistości jest - płaszczyzną konsensusu narodowo-politycznego. Rosyjska doktryna podkreśla oryginalność proponowanej strategii państwowej i narodowej, którą nazywa konserwatyzmem dynamicznym. Skrajnie różni się ona od propozycji tzw. liberalizmu konserwatywnego. Odrzuca kompromis między starym i nowym, wszelką ewolucję, postuluje zastosowanie nowych środków dla obrony świętości i tradycji. Rosyjska doktryna neguje też konserwatyzm rewolucyjny z jego iluzoryczną wiarą w możliwość odtworzenia zniszczonych instytucji państwowych. Postulowany konserwatyzm dynamiczny jest podstawą zbudowania ustroju określanego mianem „sensokracji” (смьслократия) w odróżnieniu od panującej obecnie „chaosokracji”, której instytucje pomysłodawcy zamierzają zlikwidować. Wkraczamy w czasy, twierdzą autorzy rosyjskiej doktryny, gdy Rosja wskaże całemu światu korzenie zła, podpowie, w jaki sposób wspólnie można mu się przeciwstawićs. Widzimy tu wyraźną sugestię, że Rosja musi sprostać zadaniom eschatologicznym.

${ }^{5}$ Por. H. Kowalska-Stus, Projekt Rosja. Doktryna rosyjska [w:] W poszukiwaniu prawdy. Chrześcijańska Europa między wiarq a polityka, red. U. Cierniak, Częstochowa 2010, s. 277-286. 


\section{Anna Kostina}

Socjolożka Anna Kostina, podobnie jak Fursow, porusza problem rozumienia i uniwersalności, pojmowanych jako jeden światopogląd ${ }^{6}$. Modernistyczna wspólna platforma kultury się wyczerpała. Dziś przed degeneracją mogą uratować jedynie te zasoby kultur partykularnych, narodowych, które posiadają potencjał innowacyjny i zdołają przezwyciężyć tendencje destrukcyjne. Z pewną rezerwą odnosi się do tradycji hermeneutycznej, pomocnej w niwelowaniu dystansu między kulturą współczesną a przeszłą. Docenia Heinricha Rickerta, ze względu na uznanie wartości, jako uniwersalnego medium w procesie poznania i zrozumienia. Dostrzega jednak problem w tym, że wartości przestały być traktowane w wymiarze transcendentnym i przestały pełnić rolę uniwersalną w kulturze.

\section{Rola kultury masowej}

W odróżnieniu od Fursowa Kostina dostrzega pozytywne cechy kultury masowej, która, według niej, niweluje kryzys tożsamości człowieka, wyzutego ze światopoglą$\mathrm{du}$, więc niemogącego go skonfrontować z powszechnie uznanym światopoglądem. Według badaczki kultura masowa pomaga adaptować się społeczeństwu rosyjskiemu do nowych warunków politycznych i społecznych. Tworzy procedury umożliwiające rozumienie i obieg sensów między subkulturami, wymianę wartości, wypracowanie wspólnego obrazu świata, standardów zachowań. Polemizuje z krytyką masowej kultury Herberta Marcuse (człowiek jednowymiarowy) i Ericha Fromma (wyalienowanej jednostki). Z jednej strony można przyznać badaczce rację, ponieważ wspomnianą przez nią pozytywną rolę w Rosji pełnią takie twory kultury masowej, jak: seriale prawosławne, masowa literatura prawosławna, z drugiej zaś kultura masowa może wprowadzać dezorientację aksjologiczną, to, co Fursow nazywa objawieniem szatana ludowi, co można kreślić jako ontologiczne oszustwo.

Autorka jest świadoma zasadniczej różnicy, jaka istnieje między kulturą wysoką a masową, podkreśla też, że kultura wysoka poddawana jest współcześnie standaryzacji charakterystycznej dla kultury masowej, w związku z czym zanika podstawowa rola kultury wysokiej polegająca na przekształcaniu świadomości indywidualnej w funkcje ponadindywidualnych duchowych wartości, aktualizowaniu doświadczenia historycznego. Kultura masowa utylitaryzuje konsumpcję, przyswaja formuły wystandaryzowanych zachowań w celu adaptacji jednostki w świecie urzeczowionym. Wyraża się w modzie, slangu, tatuażu... Formatuje wyobrażenia o dobru i złu, życiu

${ }^{6}$ Анна Владимировна Костина, doktor filozofii, Katedra Moskiewskiego Uniwersytetu Humanistycznego. А. В. Костина, Массовая культура: аспекты понимания, „Знание. Понимание. Умение” 2006, № 1. 
i śmierci, obowiązku i sumieniu. Temu formatowi poddaje pozostałe artefakty kultury współczesnej i przeszłej. Sama też w procesie adaptacyjnym (duża rola mass mediów) traci część swoich treści. Kostina zauważa też, że człowiek kultury masowej i mass mediów zatraca zdolność komunikacji z drugim człowiekiem na płaszczyźnie egzystencjalnej. Widzimy zatem, że ocena kultury masowej przez Kostiną w odniesieniu do roli, jaką pełni w Rosji współczesnej, jest ambiwalentna. Wydaje sięjednak, że przeważa ocena negatywna.

\section{Aleksander Dugin}

Na inne aspekty kultury masowej zwraca uwagę w swojej książce Popkultura i znaki czasu Aleksander Dugin, wpływowy ideolog polityczny, socjolog i filozof’ Mowa jest w niej o kilku ważnych zagadnieniach oraz sztuce kultury masowej.

\section{Mediokracja}

Dużo miejsca Dugin poświęca telewizji. Twierdzi, że nic bardziej nie bulwersuje jako skutek rewolucji niż to właśnie, że świat przedstawiany nam przez telewizję odbieramy jako prawdziwy, a nie dziwaczny. Utrata daru wyczuwania obcości jest oznaką przystosowania, a stopień, w jakim się przystosowaliśmy, jest miernikiem zmiany, jaka się w nas dokonała. Przystosowanie naszej kultury do epistemologii telewizji jest już niemal pełne; tak dalece przyjęliśmy jej definicje prawdy, wiedzy i rzeczywistości, że jej irrelewantny język wydaje się nam przepełniony znaczeniem, a chaos - stanem wybitnie normalnym. I jeśli niektóre nasze instytucje, według opinii mediów, wydają się nie pasować do szablonu naszych czasów, to dlaczego właśnie je, a nie ów szablon, uznajemy za odbiegające od normy i obce?

Media nobilitują świat kryminalny (seriale, thrillery, kroniki kryminalne), sugerując, że prawo jest czymś sztucznym, czysto formalnym, jego wyroki nie mają nic wspólnego z obiektywnym systemem wartości. Z drugiej strony media ferują wyroki w dziedzinie polityki, życia społecznego, za pośrednictwem talk-show imitujących salę sądową. Zastępują społeczeństwo, organa przedstawicielskie i władzę. Kiedyś media były tubą propagandową władzy; obecnie kierują do widza rozmyte postulaty zachęcające do abstrakcyjnego działania. W okresie pieriestrojki media nie propagowały odmiennych niż komunistyczne ideałów, ale zmieniły język komunikacji w celu kształtowania masowego tła psychologicznego; był to język aluzji, skojarzeń, gestów, intonacji, niuansów przy przekazywaniu informacji. Zamiast radzieckiej iluzji pojawiła się iluzja w rozpy-

${ }^{7}$ А. Дугин, Поп-культура и знаки времени, http://books.4pt.su/publikaciya-v-pdf/pop-kulturai-znaki-vremeni (dostęp: 12.06.2016). 
laczu, widowisko w rozpylaczu, zamiast widowiska scentralizowanego. Samo centrum też zniknęło. Taka jest technologia powstania dualizmu pojęć: „,reżim” i „system”, niezależność od reżimu jest, ale niezależności lub zależności od systemu nie ma.

Medialne technologie sprawiają, że podawane sądy są odbierane jako własne, oczywiste, co uprawomocnia uśredniony poziom intelektualny dziennikarzy. Oni właśnie posiadają ogromną władzę, choć nikogo nie reprezentują ani przez nikogo nie są wybierani. Media są głównym aktorem kultury postmodernizmu.

\section{Postmodernizm}

Postmodernizm w Rosji, według Dugina, ma dwa oblicza. Jedno - kolonialne. Zachodni postmodernizm stosowany przez kompradorskie elity intelektualne spełniał rolę pomocniczą w procesie przemian, demontażu radzieckiego pseudomodernizmu. Nie walczy z tradycją, gdyż jest ona dla niego przedmiotem gry widowiskowej. Drugi postmodernizm, ludowy, budzi w Duginie pewne nadzieje, może zrodzić antytelos - antycel, stać się motorem nowego mesjanizmu, przestawić kody kontrolne systemu na tory powrotu do imperium. Dugin nie potrafi określić, w jakim stopniu postmodernizm dotknął Rosję. Przypuszcza, że Rosja osunęła się weń przez przypadek przygnieciona gruzami mitu ZSRR. Żywi wiarę w to, że Rosjanie są w stanie uchwycić cel swojego przeznaczenia. Ukazać światu swój wyjątkowy, ofiarny, tragiczny los. Jako przykład przywołuje spektakle reżysera Marka Zacharowa. W czasach, kiedy teatr postmodernistyczny upada, bo nie wykracza poza błazenadę, reżyser ten ukazał nową strategię kulturową w świecie nowej ideologii. Dąży ona do tego, by zmierzyć się z własnym barbarzyństwem i herezją, bez dostrajania się do obcych norm, zrzucić sztuczne maski, pokazać własne oblicze. (Dugin recenzuje przedstawienia: Mewa Antona Czechowa i adaptację Gracza Fiodora Dostojewskiego w reżyserii Zacharowa).

\section{Rock i pop}

Dugin jest wytrwałym recenzentem rosyjskiej współczesnej kultury masowej. Twierdzi, że na jej przykładzie można obserwować zanikanie kultury. Przeciwstawia kulturę tradycji. Kultura jest zjawiskiem wtórnym. W muzyce pop i rocku dostrzega pierwiastki ożywcze tradycji, obrazowo przedstawia to słowami, że skoro rzeki zostały otrute, to trzeba szukać ratunku w kałużach. W labiryntach alienacji i dewiacji pop stwarza czarną eschatologiczną scholastykę. Rolę rosyjskiego popu w rosyjskiej kulturze współczesnej ilustruje chińską historyjką o Daosie, który chciał się nauczyć latać ${ }^{8}$.

${ }^{8}$ Neofita Daos pragnął nauczyć się latać. W tym celu udał się do nauczyciela. Ten obiecał go nauczyć po 20 latach darmowej służby. Po tym czasie, chcąc pozbyć się naiwnego idioty, nauczyciel kazał mu wspiąć 


\section{Kuriochin}

Dugin twierdzi, że w języku popu okresu pieriestrojki zakodowana została przyszłość. Najpierw pojawił się Andriej Razin jako sortownik wszelkiego zachodniego muzycznego postmodernistycznego śmiecia. Nieco później Siergiej Kuriochin, pianista jazzowy europejskiej sławy, twórca zespołu „Pop-mechanika”. Utwory tego zespołu stanowią przykład przekonującego, ciekawego, wyrazistego postmodernizmu. Nie mają nic wspólnego z naśladownictwem i eklektyzmem. Sąsiadują w nich elementy archaiczne i modernistyczne, klasyczne i awangardowe, intelektualne i groteskowe; Kuriochin odkrywał te wartości, od których odwracała się współczesna cywilizacja. Postmodernizm Kuriochina rehabilitował premodernizm, tradycję kulturową, aksjologię. Posługiwał się wszystkimi rodzajami sztuki: baletem, muzyka, melodeklamacją, teatrem, cyrkiem (zwierzęta), teatrem kukiełkowym, malarstwem, filmem.

Sam kompozytor był oryginalnym myślicielem, krytykiem współczesnej kultury, występował w cyklicznych programach telewizyjnych Siergieja Szołochowa „Tichij Dom”. Znał filozofię, historię religii, psychologię. Reprezentował petersburski nonkonformizm lat dziewięćdziesiątych. Był mistrzem dla młodych reżyserów kinowych; współtwórcą stowarzyszenia Konserwatywna Rewolucja. Chciał wśród inteligencji petersburskiej budować orientację promoskiewską, zwrócić Petersburg ku centrum świętej Rusi. Liczył na zrozumienie i solidarność. Nazywał to poszukiwaniem imienia dla tego miasta, które symbolizuje sekularyzację, okcydentalizację i pochód ku komunizmowi.

Kuriochin zmarł młodo; po śmierci utworzone zostało centrum sztuki współczesnej jego imienia.

\section{Letow}

Muzyka i poezja Jegora Letowa, lidera zespołu „Grażdanskaja oborona” odwołuje się do szeroko pojętej wysokiej kultury współczesnej: kina, malarstwa, filozofii, literatury, doktryn politycznych, systemów religijnych (twórcy: Francis Coppola, Werner Herzog, Reiner Fassbinder, Wim Wenders, Herman Hesse, Samuel Beckett, Antoine Saint-Exupéry, Antonin Artaud, Jurij Mamlejew, Leonid Andriejew; filozofowie polityki: Michaił Bakunin, Georges Sorel i Pierre Proudon). Odwołuje się do wiedzy oczytanego, wykształconego człowieka; tymczasem fanami tego zespołu są czternastoletnie dzieci. Jest to tym bardziej dziwne, że teksty Letowa są nie tylko trudne, lecz także mroczne, pesymistyczne. Dugin twierdzi, że popularność zespołu związana jest z przemianą świadomości nowego pokolenia.

Powtarzającym się motywem pieśni Letowa jest wolność kojarzona z cierpieniem, bólem, śmiercią w odróżnieniu od uwolnienia ku postępowi, który jest zakłamaną

się na wysokie drzewo i skoczyć. Ale ku rozpaczy chciwego nauczyciela kretyn wzniósł się w powietrze i zawołał: „Dziękuję nauczycielu!”. Tę sytuację Dugin określił mianem intuicji bytu - ontofania. 
wolnością. Motywy poezji Letowa Dugin odnosi do twórczości Grigorija Skoworody, Fiodora Dostojewskiego, Dmitrija Mierieżkowskiego, Władimira Sołłoguba, Andrieja Płatonowa, Jurija Mamlejewa, Władimira Chlebnikowa, Nikołaja Klujewa. Tanatofilia w tekstach Letowa uwalnia od totalitaryzmu świata, śmierć jest nauczycielem, przynosi prawdziwą wolność, jest wrogiem systemu:

- Мир или война?

- Свобода или плеть?

- Любовь или страх?

- Бог или смерть? ${ }^{9}$

$\mathrm{O}$ fenomenie rocka w rosyjskiej kulturze masowej pisała też Anna Kostina ${ }^{10}$. Charakteryzuje grupę „Король и Шут”, która wykorzystując motywy byliczek, zwraca się do archaicznych pokładów kultury ruskiej, przełamując schematy współczesnej kultury, jej subiektywizm. Odwołuje się do obrazu świata archaicznego, w którym niemożliwe było naruszenie ustanowionego porządku. Panuje etyka bohaterska. Wiernych fanów tej grupy stanowią członkowie stowarzyszeń rekonstrukcji wydarzeń historycznych.

\section{Literatura masowa}

Wielu badaczy kultury masowej zajmuje się zagadnieniem literatury masowej. Tatjana Kuzniecowa oraz Władimir i Michaił Łukowowie, powołując się na proroczą pracę Rolanda Barthes'a Śmierć autora, twierdzą że twórcy masowej beletrystyki są producentami tekstów ${ }^{11}$. Posługują się określoną technologią polegającą na powielaniu sztampowych obrazów świata, podczas gdy prawdziwi pisarze przedstawiali koncepcję świata.

Problem autora porusza także Maria Czerniak ${ }^{12}$. Zwraca uwagę nie tylko na technologiczną funkcję pisarza, lecz także na fakt, że wydawnictwa posługują się rzemieślniczymi cechami pisarzy wspólnie wytwarzających serie wyspecjalizowanych tematycznie powieści. Podaje przykład wydawnictwa Eksmo i licznych serii („Криминальная карта России”, „Милицейская академия”, „Рожденный вором”, „Русский Ниндзя”, „ФСБ. Русский 007”, „Турецкий и его команда”, „Я - вор в законе" i inni). Występują też seryjne tytuły (Л. Гурский, Спасти президента, Убить президента; У. Абдуллаев, Совесть негодяев, Кредо негодяев, Закон

${ }^{9}$ Е. Летов, Гражданская оборона - войнаб, http://www.gr-oborona.ru/texts/1056900819.html (dostęp: 11.10.2016).

${ }^{10}$ А. Костина, Массовая культура: архаические истоки или «новая религиозность»?, http:// www.mosgu.ru/nauchnaya/publications/2009/professor.ru/Kostina_AV.pdf (dostęp: 12.06.2016).

${ }^{11}$ Т. Кузнецова, В. Луков, М. Луков, Массовая культура и массовая беллетристика, http://www. zpu-journal.ru/e-zpu/2008/4/kuznetsova\&lukovs/ (dostęp: 12.06.2016).

${ }^{12}$ М. Черняк, Категория «автора» в массовой литературе; idem, Феномен массовой литеpaтуры ХХ века, Изд-во РГПУ им. А. И. Герцена, Санкт-Петербург 2005, s. 152-178, https://docviewer. yandex.ru/?url= (dostęp: 12.06.2016). 
негодяев; А. Воронин, Лабиринт для Слепого, Мишень для Слепого, Слепой стреляет без промаха; А. Золотько, Под позолотой - кровь, Под кровью - грязь, Под грязью - пустота; И. Львова, Стелла искушает судьбу, Стелла делает выбор, Стелла обманывает смерть; Н. Корнилова, Пантера: ярость и страсть, Пантера: черная молния, Пантера: за миг до удара). Czytelnicy nie posługują się nazwiskami autorów, tylko numerami serii. Nazwisko figurujące na okładce staje się logo. Oskarża się znanych pisarzy, Darię Doncową, Aleksandrę Marininę, Czingiza Abdułajewa i Maksa Fraja, że udzielają swojego „logo” wielu rzemieślnikom. Doncowa w ciągu czterech lat wydała 50 książek.

Popytem cieszy się proza pisana przez kryminalistów. Jewgienij Monach, który odsiedział 18 lat, jest autorem kryminałów: Братва: кровь за кровь, Братва: пошады не будет, Кровь смывает все следы. Swoją pierwszą powieść Смотрю на мир глазами волка napisał w celi. Anton Iwanow i Anna Ustinowa napisali ponad 20 kryminałów dla uczniów w serii „Czarny Kotek”.

Powieści stają się częścią narracji transmedialnej: serial, komiks, gra komputerowa. Czytelnik staje się uczestnikiem gry, a nawet pisarzem, ponieważ program komercyjny zakłada, że jeśli dopiszesz wątek dalszego ciagu powieści, to dostaniesz ją za darmo. Publikuje się poradniki, jak zostać pisarzem.

Ministerstwo Spraw Wewnętrznych nagrodziło serial Улиць разбитых фонарей za podwyższenie prestiżu policji. Oficerowie GRU: Michaił Niestierow, Siergiej Samarow i pisarz Siergiej Moskwin są autorami scenariusza serialu antyterrorystycznegо Спецназ.

\section{PODSUMOWANIE}

Przywołane tu poglądy rosyjskich socjologów kultury: Fursowa i Dugina charakteryzują się przenikliwością, ukazują odległa genezę zjawisk, są syntetyczne. Oparte są na zakorzenionym w tradycji rusko-bizantyjskiej systemie widzenia rzeczywistości. Dlatego, by te diagnozy zrozumieć, trzeba znać ten system. Specyfikąrosyjskiej socjologii kultury jest krytyczny stosunek do zachodniej metodologii, czerpanie z własnych wzorców humanistyki, która nie poddaje się presji metodologii nauk społecznych. Na szczególną uwagę zasługuje nieuleganie modnym tematom, jak: multikulturowość, gender, kultura miejska, studiowanie subkultur i innych niszowych zjawisk. Cenne jest postawienie przez nią w centrum uwagi człowieka, jako współtwórcę kultury, posiadającej eschatologiczne znaczenie i cele. Antropologia jako główne zagadnienie socjologii kultury w ujęciu rosyjskim nie ma nic wspólnego z antropologią kulturową w badaniach zachodnich ${ }^{13}$.

${ }^{13}$ Podaję typowe tematy polskich badań w dziedzinie socjologii kultury: M. Golka, Żywe rzeźby w przestrzeniach miast, Poznań 2014; idem, Imiona wielokulturowości, Warszawa 2010; idem, Socjologia artysty, Poznań 1995; W. Burszta, Antropologia kultury. Tematy, teorie, interpretacje, Poznań 1998; idem, Asteriks w Disneylandzie. Zapiski antropologiczne, Poznań 2001. W znanej w polskim środowisku 
Badacze podkreślają, że we współczesnej rzeczywistości kulturowej najbardziej zagrożony jest człowiek jako podmiot. Dlatego trzeba skoncentrować się na nim. Sama globalizacja $\mathrm{z}$ jej kulturą ma o wiele mniejsze znaczenie lub jej istnienie jest wręcz negowane. Natomiast głównym zadaniem dla współczesnego człowieka jest pozostanie człowiekiem. Dlatego, aby zdiagnozować współczesną popkulturę, nie wystarczy analizować jej poszczególnych zjawisk, lecz trzeba potraktować ją jako skutek niewłaściwego ukierunkowania kultury chrześcijańsko-europejskiej. Całkowicie nieznane $\mathrm{w}$ badaniach zachodnich jest zagadnienie eschatologizmu kultury zwane przez Fursowa historyczno-systemową finalistyką. Dlatego krytyce poddany został, wylansowany przez Rousseau, prezentyzm, będący normą współczesnej popkultury.

\section{Literatura}

Kowalska-Stus H., Projekt Rosja. Doktryna rosyjska [w:] W poszukiwaniu prawdy. Chrześcijańska Europa między wiarq a polityka, red. U. Cierniak, Częstochowa 2010, s. 277-286.

Дугин А., Поп-культура и знаки времени, http://books.4pt.su/publikaciya-v-pdf/popkultura-i-znaki-vremeni.

Костина А. В., Массовая культура: аспекты понимания, „Знание. Понимание. Умение" 2006, № 1.

Костина А., Массовая культура: архаические истоки или «новая религиозность»?, http://www.mosgu.ru/nauchnaya/publications/2009/professor.ru/Kostina_AV.pdf.

Кузнецова Т., Луков В., Луков М., Массовая культура и массовая беллетристи$\kappa a$, http://www.zpu-journal.ru/e-zpu/2008/4/kuznetsova\&lukovs/.

Проект «Россия». Исследовательский доклад группь «интелрос», http://www. intelros.org/lib/doklady/russia.htm.

Фурсов А., Вирусныле элиты и Русская культура, 10 января 2014, http://omiliya. org/article/andrei-fursov-virusnye-elity.

Фурсов А., Колокола истории, http://royallib.com/read/fursov_andrey/kolokola istorii.html\#20480.

Черняк М., Категория «автора» в массовой литературе; Феномен массовой литературы ХХ века, Изд-во РГПУ им. А. И. Герцена, Санкт-Петербург 2005.

książce Jeffreya C. Alexandra Znaczenia społeczne autor krytycznie ocenia metodologię, w której znaczenie zjawisk kulturowych wiąże się ze strukturą społeczną lub fenomenologicznie ujętą strukturą wartości. Kultura jawi się jako zależna od zmieniających się czynników społecznych. Także badacz krakowski, L. Korporowicz w swojej książce Socjologia kulturowa (Kraków 2011) proponuje odwrócenie kierunku badań od kultury do społeczeństwa. Przyjmuje, że kultura jest autonomiczna. 